teeth about two feet apart which have a design and resilient lift that will enable them to carry and push logging debris. Stumps are cut twelve inches or less in height above the ground, and dead standing timber is readily pushed over.

During the course of the test, at which a Caterpillar Tractor Company and Fleco Rack Rake representative was present, the machine pushed and carried logging debris for about two and one-half chains distance into windrows. These windrows piled in the cut-over areas will be burned in early winter when a light fall of snow covers the ground.

The ground thus received favorable scarification both by the action of pushing debris and by the tracks of the machine.

It was considered by those observing the experiment that the ground thus prepared was quite receptive to tree seed and resultant regeneration. Further tests are planned in the near future and those concerned are fully confident of achieving the desired results at a reasonable cost.

Contributed by CHARLES JACKSON

\title{
FARRAR JoINS U OF T STAFF
}

Dr. John L. Farrar, senior research officer at the Petawawa Forest Experiment Station, Chalk River, has been appointed to the newly established chair of forest biology in the Faculty of Forestry, University of Toronto.

The grant of $\$ 10,000$ a year for ten years to the University recently announced by the Abitibi Power and Paper Co. Ltd. enables establishment of this chair. If two additional chairs in the Faculty of Forestry--Forest Economics and Forest Pathology - can be established, the Faculty of Forestry will take an outstanding place in the front ranks of schools of forestry throughout the world, said President Sidney Smith.

Mr. D. W. Ambridge, president of Abitibi, has long recognized that business must be interested in universities, and that if many companies are to stay in business they must be interested in universities for the training of qualified personnel.

A graduate of the University of Toronto, Dr. Farrar earned his master's and doctor's degrees at Yale. He was a radar officer in the R.C.A.F. from 1941 to 1945 . He is the author of over 30 published papers on silviculture, forest reproduction, vegetative propagation, tree breeding, forest ecology and tree physiology.

Dr. Farrar will transfer his activities from Petawawa and Ottawa to the University forest in Haliburton county and to the Glendon Hall estate on Bayview Avenue, Toronto, where he will work closely with other Ontario groups in government and industry, and with the University Department of Botany. Research to be done in tree physiology and forest ecology will include the study of the effect of various environmental factors such as length of day; light intensity; soil moisture; and soil nutrients on the germination, establishment, and early growth of different species and strains of forest trees. The results are expected to be of great benefit to the Province's forest economy. 